\title{
VARIACIONES SOBRE UN MISMO TEMA: EL ARTE RUPESTRE ASOCIADO AL COMPLEJO PICA-TARAPACÁ, NORTE DE CHILE*
}

\author{
VARIATIONS ON A THEME: \\ ROCK ART ASSOCIATED WITH THE PICA-TARAPACÁ \\ COMPLEX, NORTHERN CHILE
}

\author{
Flora Vilches $^{1}$ y Gloria Cabello ${ }^{2}$
}

\begin{abstract}
Se presenta una síntesis de los resultados relativos al arte rupestre asociado a sitios habitacionales obtenidos durante cuatro años de investigación en la porción septentrional de la región de Tarapacá. Específicamente, se discute la variabilidad iconográfica tanto intra como intersitio, pudiendo establecer un repertorio común de imágenes que actúan de forma diferencial en cada asentamiento. Asimismo, se discute el rol que habría cumplido el arte rupestre a nivel regional durante el período Intermedio Tardío. De especial interés es el diálogo que se establece entre la información reportada, que pertenece al ámbito de lo privado, y aquella propia del ámbito público, es decir, no vinculada a sitios habitacionales aunque de reconocida presencia en la región.
\end{abstract}

Palabras claves: arte rupestre, Pica-Tarapacá, iconografía, sitios habitacionales, identidad.

This article presents a synthetic view of rock art iconography associated with habitation sites in the northern portion of the Tarapacá region. Specifically, we discuss the data in relation to its iconographic variability, both intra-and inter-site, establishing a common set of images that function differently at each settlement. Moreover, we discuss the role that rock art might have played on the regional level during the Late Intermediate Period. Special attention is given to the dialogue between the information reported here -which belongs to the private sphere- and that of the public sphere, which is well-known in the region although not associated with habitation sites.

Key words: Rock art, Pica-Tarapacá, iconography, habitation sites, identity.

En 1985, Lautaro Núñez se refiere a una serie de petroglifos de la región de Tarapacá interpretándolos como parte de una compleja red de intercambio existente entre sus productores. Sin embargo, como él mismo reconoce, su enfoque metodológico no alcanza a explicar cuáles grupos se desplazan, quiénes producen las representaciones rupestres, y por qué; aunque según él, sus propuestas interpretativas "no excluyen el significado ceremonial [de los grabados] y se suman a tratar de entender el significado simbólico del tráfico interregional" (Núñez 1985:262).

En este artículo sintetizamos los resultados de investigaciones en torno al arte rupestre de sitios habitacionales del Complejo Pica-Tarapacá (sensu Uribe 2006), con especial énfasis en su dimensión iconográfica. Además, se compara con la extensa serie de antecedentes sobre ámbitos públicos, vale decir, aquellos sitios no asociados a pisos ocupacionales y donde el arte rupestre constituye la única evidencia arqueológica, como el caso de los petroglifos a los cuales se refería Núñez (1985). Este trabajo pretende, por lo tanto, contribuir a comprender más cabalmente el rol que cumplía el arte rupestre en esta región; en otras palabras, quién lo producía, cómo y por qué.

Nuestras investigaciones fueron desarrolladas en el marco de un estudio de mayor envergadura en la región de Tarapacá, cuyo principal objetivo ha sido comprender arqueológicamente los sistemas sociales que desarrollaron poblaciones jerarquizadas y segmentarias como las del Complejo Cultural Pica-Tarapacá (1.000-1.450 d.C.) (Uribe 2006). Dichas comunidades, ubicadas entre las quebradas

* Este estudio fue presentado en el simposio sobre Arte Rupestre de los Andes, realizado en el $52^{\circ}$ Congreso Internacional de Americanistas, Sevilla, julio de 2006. La edición de los artículos seleccionados para este número de la Revista estuvo a cargo de Marcela Sepúlveda y Jean Guffroy.

1 Departamento de Antropología, Universidad de Chile, Santiago, Chile. floravilches@ gmail.com

2 Centro de Investigaciones del Hombre en el Desierto, Universidad de Tarapacá, Arica, Chile. glcabello@ gmail.com 
y oasis interiores de Camiña y el río Loa, se despliegan en un espacio que presenta una gran variedad de ambientes y ecosistemas, lo que les permite desarrollar una amplia gama de especializaciones socioeconómicas. Tal como lo señala Uribe "creemos que la heterogeneidad expuesta responde a la desigualdad social que se ha desarrollado con el tiempo en los Valles Occidentales, correspondiente a una competencia por reproducir en más espacios esa formación social" (Uribe 2006:111). A lo largo de este artículo, discutiremos de qué manera el arte rupestre participa de aquella visión de Complejo propuesta por Uribe (2006) para Pica-Tarapacá. Primeramente, nos abocaremos a describir y comprender el comportamiento de las expresiones parietales en los sitios habitacionales estudiados, para luego abordarlos dentro de una perspectiva regional.

\section{La Iconografía del Arte Rupestre Doméstico: Material, Método y Datos}

De un total de 11 sitios habitacionales estudiados por el equipo de Uribe (2006) en la región, cinco presentaron evidencias de arte rupestre: Camiña-1, Tarapacá Viejo, Jamajuga, Chusmisa y Pukarqollu (Figura 1) ${ }^{1}$. De esta manera, los resultados que arroja el arte rupestre de asentamientos asociados al Complejo Pica-Tarapacá permiten complementar los trabajos rupestres previos en la zona (Llamazares 1993; Moragas 1993; Moreno 1986; Mostny 1970; Núñez 1976; Núñez y Briones 1967-68; Tolosa 1967; entre otros) que, en su mayoría, han interpretado la evidencia en relación a ceremonias ligadas al tráfico de caravanas desarrollado durante el Intermedio Tardío. De ellos se desprende que por tratarse de sitios de paso, aquellas actividades rituales estaban restringidas a grupos más bien pequeños en tránsito, cumpliendo el arte rupestre, en este caso y fundamentalmente, funciones cúlticas y/o de señalética.

Tal como lo hemos señalado en otras publicaciones, donde se detalla cada sitio estudiado (Vilches 2006; Vilches y Cabello 2006, 2010), las representaciones rupestres de contextos habitacionales se presentan casi exclusivamente como grabados. Estos tienden a concentrarse en sectores eminentemente domésticos dentro de cada asentamiento, particularmente en estructuras de depósitos o cistas que muchas veces fueron utilizadas con fines funerarios. Junto con indicar que se trata de poblaciones con orientación agrícola, el marcado de espacios claramente cotidianos habla de la integración del sistema económico al dominio ritual y, a su vez, de la preeminencia de ciertos individuos en el culto a los antepasados que es necesario subrayar ( $c f r$. Adán y Urbina 2005).

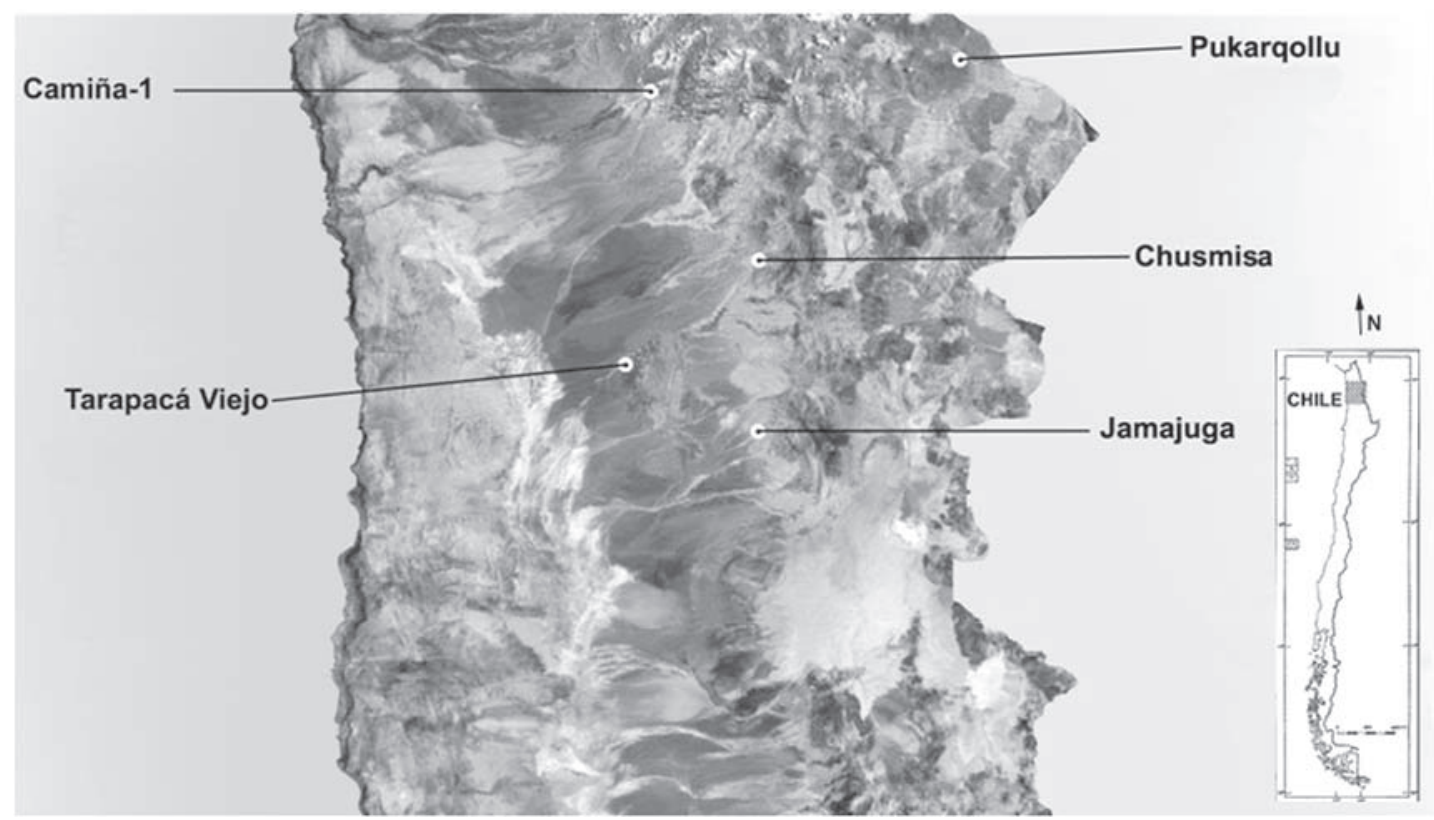

Figura 1. Mapa con sitios habitacionales con arte rupestre.

Map indicating habitation sites with rock art. 
En términos generales, la dimensión iconográfica del arte rupestre de asentamientos reveló la existencia de tres grandes grupos: geométrico, antropomorfo y zoomorfo, con amplia variabilidad de motivos al interior de cada uno. Cabe señalar que optamos por un análisis de carácter iconográfico, donde la unidad mínima de análisis fue el panel en virtud de la abultada cantidad de figuras en cada uno de ellos. Esto nos permitió también realizar un trabajo comparativo en la totalidad de los sitios estudiados, entre los cuales el número de bloques era heterogéneo: Chusmisa $=178$, Camiña $=44$, Jamajuga $=31$, Tarapacá Viejo $=21$ y Pukarqollu $=2$. Además, entendemos este acercamiento como una primera etapa de aproximación al material la que, en el futuro, puede ser complementada con otro tipo de análisis, ya sea de carácter estructural o tecnológico. Asimismo, abordar este gran universo rupestre desde la iconografía nos permite entender estos nuevos contextos habitacionales dentro de la extensa esfera regional hasta ahora conocida principalmente en términos iconográficos. Pensamos que a partir de una discusión comparativa de ambos registros -habitacional y no habitacional- nos será posible acercarnos a una mejor comprensión de quiénes eran los productores del arte rupestre.

A continuación presentamos y discutimos en extenso la tipología de motivos iconográficos originada a partir de nuestro registro. Se trata de un inventario de imágenes (Tabla 1) realizado a partir de las categorías propuestas por Núñez y Briones (1967-68) las que nos permiten aunar conceptos

Tabla 1. Síntesis de presencia y ausencia de las categorías propuestas para cada sitio. Summary of the presence and absence of proposed categories for each site.

\begin{tabular}{|c|c|c|c|c|c|}
\hline Categoría / sitio & Tarapacá Viejo & Jamajuga & Camiña 1 & Chusmisa & Pukarqollu \\
\hline círculo & $X$ & $X$ & $\mathrm{X}$ & $\mathrm{X}$ & \\
\hline círculo con punto central & $X$ & $\mathrm{X}$ & $\mathrm{X}$ & $\mathrm{X}$ & \\
\hline círculos concéntricos & & $\mathrm{X}$ & $\mathrm{X}$ & $\mathrm{X}$ & \\
\hline círculo con apéndice externo & & $\mathrm{X}$ & $\mathrm{X}$ & $X$ & \\
\hline círculo yuxtapuesto & & $\mathrm{X}$ & $\mathrm{X}$ & $\mathrm{X}$ & \\
\hline círculo con división interior & & $\mathrm{X}$ & & $X$ & \\
\hline círculo relleno o punto & & $X$ & & $\mathrm{X}$ & \\
\hline círculo radiado & & & $\mathrm{X}$ & $\mathrm{X}$ & \\
\hline espiral & & & & $X$ & \\
\hline semicírculo & & & & $X$ & \\
\hline zigzag & & $\mathrm{X}$ & $\mathrm{X}$ & $X$ & \\
\hline figura geométrica indefinida & & $\mathrm{X}$ & $X$ & $\mathrm{X}$ & \\
\hline triángulo & & $\mathrm{X}$ & $\mathrm{X}$ & & \\
\hline rectángulo o cuadrado & & $X$ & $\mathrm{X}$ & & \\
\hline figura de formas diversas o grecas & & & $\mathrm{X}$ & $X$ & \\
\hline fitomorfos & & & $X$ & $X$ & \\
\hline figura o signo no identificado & & & $\mathrm{X}$ & $X$ & $X$ \\
\hline estrella & & & & $\mathrm{X}$ & \\
\hline ornitomorfo de cuerpo lleno & & $X$ & & $X$ & \\
\hline ornitomorfo esquematizado lineal & & & $X$ & $\mathrm{X}$ & \\
\hline saurios y batracios & & $\mathrm{X}$ & $\mathrm{X}$ & & \\
\hline cánidos y roedores & & $\mathrm{X}$ & $\mathrm{X}$ & $\mathrm{X}$ & \\
\hline felino & & & $\mathrm{X}$ & $\mathrm{X}$ & \\
\hline camélido complejo & & & & $X$ & \\
\hline camélido simple & $X$ & $X$ & $\mathrm{X}$ & $\mathrm{X}$ & \\
\hline insecto & & & $\mathrm{X}$ & $\mathrm{X}$ & \\
\hline zoomorfo indeterminado & & $X$ & & $\mathrm{X}$ & \\
\hline figura humana esquematizada & $X$ & & & $\mathrm{X}$ & \\
\hline figura humana dinámica & & & & $\mathrm{X}$ & \\
\hline figura humana compleja & & $X$ & $\mathrm{X}$ & $\mathrm{X}$ & $X$ \\
\hline pie & & & & $X$ & \\
\hline antropozoomorfo indeterminado & & & $X$ & $\mathrm{X}$ & \\
\hline
\end{tabular}


ampliamente utilizados para la zona. Las múltiples relaciones generadas entre cada elemento nos permiten ir deslindando las peculiaridades de cada asentamiento, así como las relaciones entre cada uno de ellos que detallaremos en las siguientes secciones.

\section{El Grupo Geométrico}

Este tipo de figuras es mayoritario en todos los sitios estudiados y cuenta con 15 motivos diferentes, originados a partir de círculos, triángulos, rectángulos y líneas. Entre las variaciones del círculo cabe destacar que sólo el círculo en sus expresiones más básicas -simple (Figura 2: A1-A9) y con punto central (Figura 2: B1-B11) - está presente en la totalidad de los sitios, con excepción de Pukarqollu. La mínima expresión de esta figura geométrica y nuestro nivel de análisis no permiten hacer mayores diferencias, sino más bien sugerir una homogeneidad en su modo de representación ${ }^{2}$. En el resto de las variantes, en cambio, existe una heterogeneidad interesante de explorar. Por ejemplo, "círculos concéntricos" y "círculos con apéndice externo" sólo se presentan en tres de los cinco sitios, variando entre ellos la complejidad de la representación (entendida ésta exclusivamente como la suma de elementos a la figura básica). En la primera de estas categorías, esta complejidad es ascendente si comparamos los casos de Jamajuga, Chusmisa y Camiña (Figura 2: B12, B13 y B14 respectivamente); y en la segunda, la complejidad se disputa entre Chusmisa (Figura 2: C13-C15) y Camiña (Figura 2: C5-C9), siendo más bien simples en Jamajuga (Figura 2: C10-C12).

De forma similar, los "círculos yuxtapuestos" en Tarapacá Viejo (Figura 2: D1) y Camiña (Figura 2: D2-D5) aparecen sólo como "simples aglutinados", mientras en los otros dos sitios como "simples unidos por líneas"; en Jamajuga siguiendo una orientación oblicua (Figura 2: D6-D7) y en Chusmisa adoptando formas más complejas (Figura 2: D8-D11). Aún más restringidos son los casos de "círculo con división interior" y "círculo relleno o punto", presentes sólo en Chusmisa (Figura 2: C4 y H4-H5) y Jamajuga (Figura 2: C1-C3 y H1-H3). Si bien en ambos sitios encontramos motivos que pueden agruparse bajo estas categorías, cada uno adquiere una forma particular y propia. El "círculo radiado", en cambio, está sólo en Camiña (Figura 2: E1 y E2) y Chusmisa (Figura 2: E3-E13), teniendo prácticamente una forma diferente en cada caso representado. Incluso, es a partir de esta figura que se genera la única variante observada de "círculo con figura en su interior"; en este caso un motivo ornitomorfo, que es exclusiva en Chusmisa (Figura 2: E14) ${ }^{3}$. Es también en este sitio donde solamente se presentan las variantes "espiral" (Figura 2: F1-F3) y "semicírculo" (Figura 2: G1-G3).

La más alta presencia y mayor variabilidad en lo que se refiere al resto de figuras geométricas, las lineales (Figura 3 y Figura 4), se da también en Camiña y Chusmisa. Si bien en Jamajuga tenemos "zigzag" (Figura 3: B2) y "figura geométrica indefinida" (Figura 3: C8-C9), su representación es mucho más simple de la que podemos observar para los otros dos sitios (para Camiña Figura 3: B1 y Figura 4: C1-C7; y para Chusmisa Figura 3: B3-B5 y Figura 4: C10-C14). Jamajuga y Camiña comparten asimismo la presencia de "triángulo" (Figura 4: B1 y B2, respectivamente) y "rectángulo o cuadrado", si bien éste se presenta en su forma simple en Jamajuga (Figura 3: F1 y F2), pero que adopta en Camiña su variante "con pestañas" (Figura 4: A1).

A partir de lo anterior, podemos identificar en Jamajuga cierta tendencia a representar las figuras geométricas en sus expresiones mínimas, contrariamente a lo que ocurre en Camiña y Chusmisa. En estos dos últimos sitios encontramos una gran cantidad de figuras lineales de alta complejidad, que podemos separar en las categorías de: "figuras de formas diversas" o "grecas" (Figura 3: A1-A7 en Camiña y A8-A17 en Chusmisa), aquellas que asemejamos a "fitomorfos" (Figura 4: D1, Camiña, y D2-D7 Chusmisa) y las "figuras" o "signos no identificados" (Figura 3: C1 Y C2 para Camiña y C4-D9 en Chusmisa). Si bien en esta última categoría incluimos el motivo de Pukarqollu, su simpleza no tiene comparación con los anteriormente señalados (Figura 3: C3). Cabe destacar que existe una última categoría dentro este grupo, la "estrella" (Figura 3: E1), que sólo está presente en Chusmisa y de manera única.

\section{El Grupo Zoomorfo}

En lo que respecta a este grupo (Figura 5), los motivos ornitomorfos están presentes en Jamajuga, Camiña y Chusmisa, pero mostrando formas muy particulares en cada sitio. Entre los "ornitomorfos de cuerpo lleno", los de Jamajuga se presentan con las alas extendidas y sumamente esquematizados y 


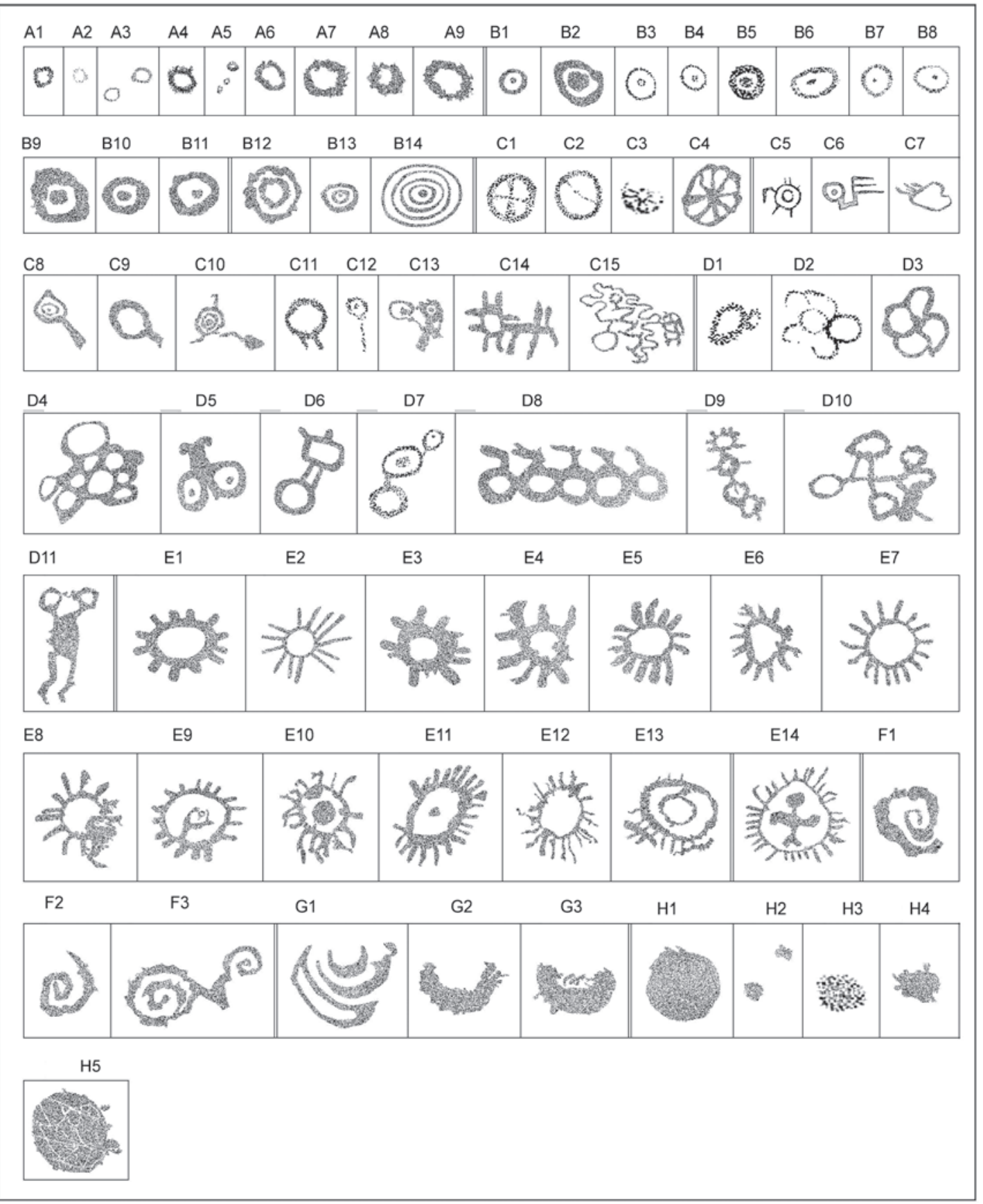

Figura 2. Grupo geométrico circular (Dibujo: Paulina Chávez). Circular geometric group (Drawing: Paulina Chávez).

simétricos en sus formas (Figura 5: A1). En Chusmisa, en tanto, son completamente diferentes, incluso entre ellos, pareciendo retratar al ñandú o suri (Rhea sp.) de cuerpo frontal pero cabeza de perfil, con las alas semiflectadas como si las batieran (Figura 5: A2); flamenco o parina (Phoenicopetrus sp.) de perfil (Figura 5: A3); y dos animales que reconocemos como aves por la curvatura de sus dos patas y cuello largo, que correspondería a la especie recién mencionada, pero más esquematizada (Figura 5: A4). La 


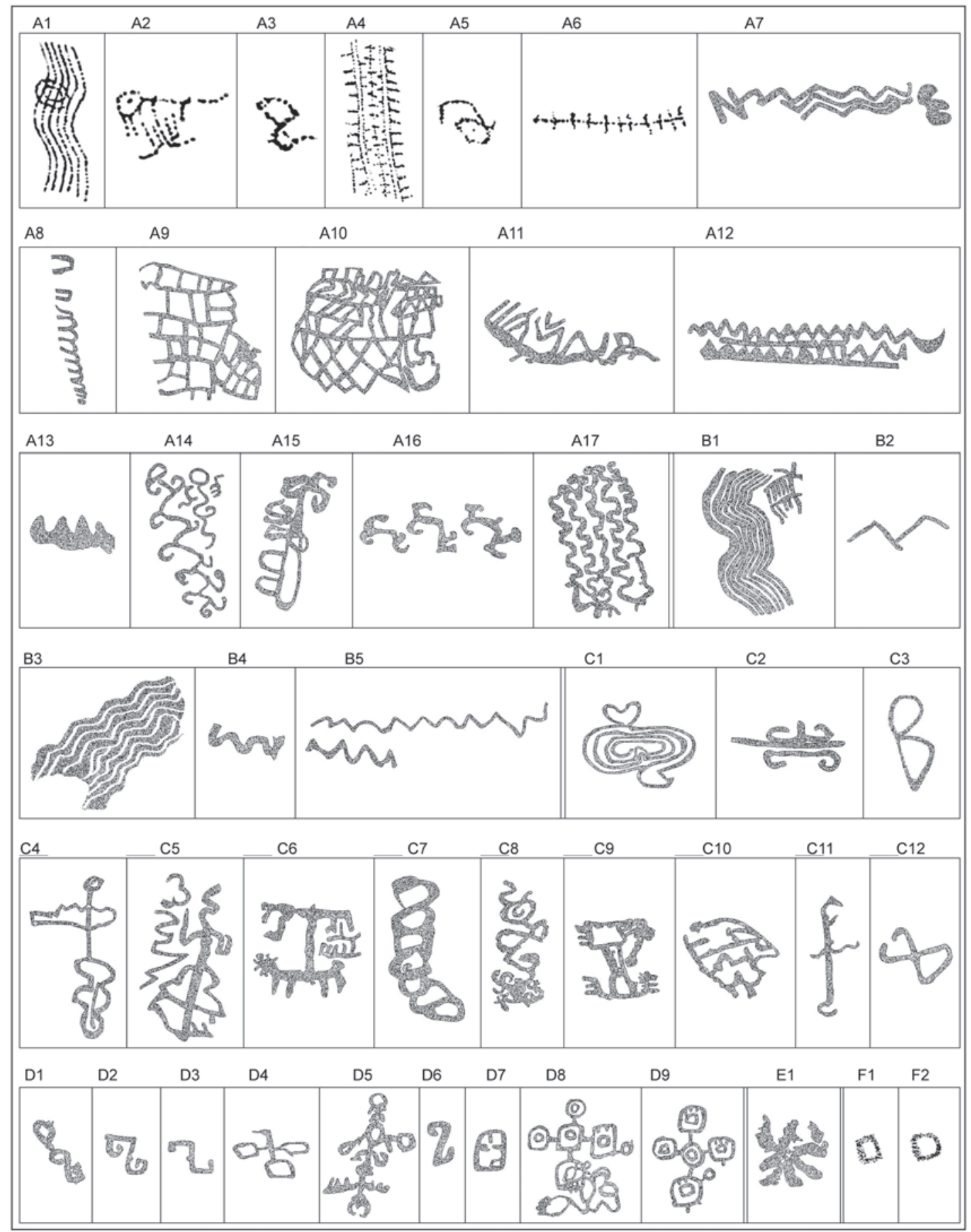

Figura 3. Grupo geométrico lineal I (Dibujo: Paulina Chávez). Linear geometric group I (Drawing: Paulina Chávez).

categoría "ornitomorfo esquematizado lineal", en cambio, se presenta sólo en Camiña (Figura 5: A5) y en Chusmisa (Figura 5: A6-A9). Este último sitio muestra una mayor variabilidad en la representación.
Si bien todos comparten los "apéndices paralelos a modos de plumas", sólo dos de ellos (Figura 5: A6 y A7) se ajustan al modelo de falcónida propuesto por Chacama (2003). 


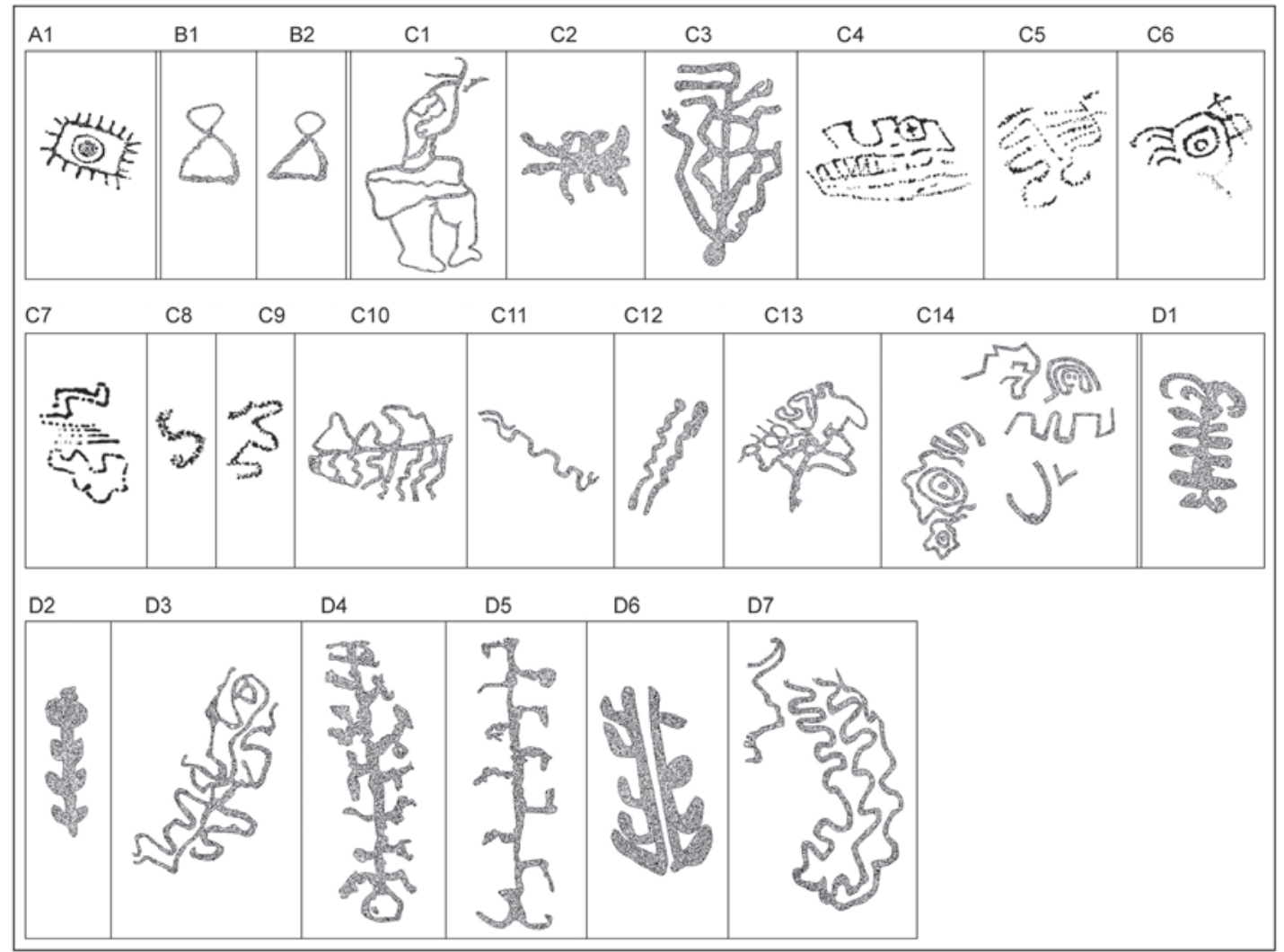

Figura 4. Grupo geométrico lineal II (Dibujo: Paulina Chávez). Linear geometric group II (Drawing: Paulina Chávez).

"Saurios y batracios" son observados únicamente en Jamajuga y Camiña, con la gran diferencia que en el primer sitio se presenta de forma lineal, sumamente esquemático (Figura 5: B3). En el segundo, en cambio, las dos especies son representadas de forma naturalista y aplicando la técnica de raspado areal que forma motivos de cuerpo lleno (Figura 5: B1 y B2). Importante nos parece destacar aquí que el sapo (Figura 5: B2) se encuentra dispuesto en el mismo panel que la única representación clara de zorro (Figura 5: C2), que reconocemos gracias a su refinado naturalismo. Esta yuxtaposición nos remite inevitablemente a la relación entre Lari y Jamp'atu señalada por Espinosa (1998).

En lo referido a cuadrúpedos, resulta especialmente difícil diferenciar especies, pero aunando criterios (Artigas y Cabello 2004; Núñez y Briones 1967-68) identificamos cánidos y roedores en Chusmisa y Jamajuga. En este último sitio encontramos cánidos representados de forma simple y con proporciones más bien equivalentes (Figura 5: $\mathrm{C} 1$ ), reconociéndolo concretamente como perro por la escena que conforma con un motivo antropomorfo. Es, otra vez, en Chusmisa donde encontramos la más alta variabilidad para esta categoría: potenciales roedor y zorros (Figura 5: C3; C4 y C5, respectivamente), así como cuatro formas distintas de representar posiblemente a perros (Figura 5: C6-C9). A la representación de felino asociamos sólo cuadrúpedos en Camiña (Figura 5: C10) y en Chusmisa, donde encontramos dos variantes (Figura 5: C11-C12).

En estos últimos sitios observamos sólo dos casos del "camélido complejo", que se ubican en esta categoría porque presentan elementos extrasomáticos, en este caso un apéndice lineal en el sector del hocico, el cual hemos interpretado como cuerda (Figura 5: C13 y C14). El caso de Camiña es relevante ya que es la única pintura del sitio. El de Chusmisa, por su parte, presenta además en el lomo un pequeño apéndice que no puede -de momento- más que señalarse como anecdótico. "Camélidos simples", en cambio, se encuentran en todos los sitios, salvo en Pukarqollu. La forma 


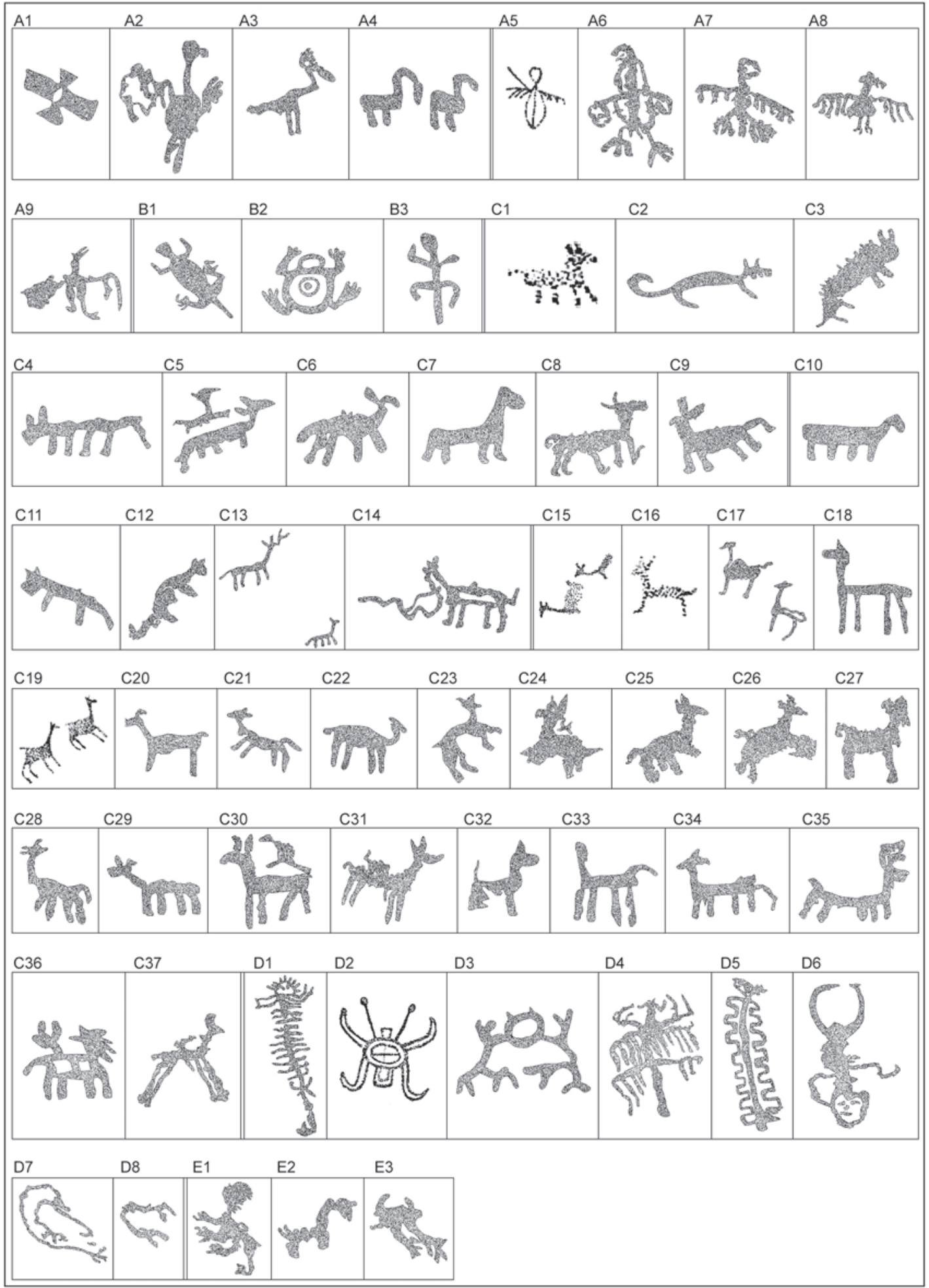

Figura 5. Grupo zoomorfo (Dibujo: Paulina Chávez).

Zoomorphic group (Drawing: Paulina Chávez). 
de representarlos es muy variada, sobre todo en Chusmisa (Figura 5: C23-C37), donde se observan algunos muy esquemáticos (Figura 5: C32 y C33), al igual que en Jamajuga (Figura 5: C18). Al mismo tiempo, existen representaciones más naturalistas que se presentan en pares dispuestos de forma oblicua en Tarapacá Viejo, Jamajuga y Camiña (Figura 5: C15; C17 y C19, respectivamente).

Por otro lado, la presencia de insectos en el arte rupestre de los sitios habitacionales nos resulta de gran interés, ya que se repiten posibles miriápodos (Figura 5: D1, D5 y D7) y coleópteros (Figura 5: D2, D3 y D6) en Camiña y Chusmisa. En ambos sitios observamos también un posible díptero y una figura que identificamos como tenazas de insecto (Figura 5: D4 y D8, respectivamente).

Finalmente, algunos motivos de Chusmisa de dudosa definición fueron reunidos en la categoría de "zoomorfos indeterminados" (Figura 5: E1-E3).

\section{El Grupo Antropomorfo}

Este es el grupo más determinante en términos iconográficos (Figura 6), ya que si bien existe una gran variedad en la forma de representar al ser humano, se observan similitudes relevantes. Aunque contamos con ejemplares de "figura humana esquematizada" sólo en Tarapacá Viejo (Figura 6: A1) y en Chusmisa (Figura 6: A2-A8), podemos ver que en la mayoría de los casos ésta se representa con un tronco engrosado, que puede seguir una tendencia circular o cuadrangular, sea relleno o vacío. Muchos de ellos también muestran pies. Y en Chusmisa es recurrente representarlos con los antebrazos extendidos a la altura del hombro y los brazos cayendo paralelos, pero separados del cuerpo.

Los únicos casos de "figura humana dinámica" se registran en Chusmisa, logrando el efecto de movimiento mediante la oposición del ángulo de abertura de los brazos (Figura 6: B1). Este también se insinúa a través de cierto quiebre en la rigidez de las extremidades inferiores (Figura 6: B2 y B3), manifestándose claramente con una curvatura acentuada (Figura 6: B4-B6), a la cual puede sumarse la curvatura del tocado o pelo (Figura 6: B4). En ciertos casos (Figura 6: B5 y B6), los motivos se presentan en parejas enfrentadas, sugiriendo al observador una escena de baile. Por último, nos parece relevante remarcar que todas las representaciones humanas dinámicas poseen algún complemento de vestimenta, sean tocados o túnicas.
Estos atributos de vestir nos dan pie para entrar en la categoría de "figura humana compleja", presentes en todos los sitios salvo en Tarapacá Viejo. $\mathrm{Si}$ bien en este conjunto se agrupan igualmente motivos esquemáticos asociados directamente a otros seres humanos (Figura 6: C1, C16 y C17), a animales (Figura 6: C18) o a figuras geométricas indefinidas (Figura 6: C13-C15), es la vestimenta lo que destaca al grupo. En Camiña los antropomorfos tomados de la mano tienen cabezas planas que podrían estar representando gorros (Figura 6: C1). Lo mismo para el caso de Pukarqollu (Figura 6: $\mathrm{C} 2$ ), en cuya cabeza triangular se alargan un poco los ángulos de base, permitiéndonos asociarlos a un gorro si los comparamos con un motivo muy similar de Chusmisa (Figura 6: C8), el cual presenta además una línea ondulada en la mano derecha que nos hace pensar en una cuerda. Poco definibles también son los atributos de otra de las figuras (Figura 6: C12), cuya línea recta en la mitad del tronco podría corresponder a un faldellín.

En términos más específicos pudimos reconocer, en la única forma de representar los antropomorfos de Jamajuga, "túnicas triangulares con orillas de urdimbre curva" que corresponden a la vestimenta característica de las poblaciones Pica-Tarapacá (Agüero 2007; Vilches y Cabello 2010: Figura 2). A ello se sumaría la presencia de gorros planos con apéndices laterales (Figura 6: C3 y C4) que podrían corresponder a los característicos gorros con coletas (Agüero 2007: Figura 17 a y d). Interesante nos parece además agregar que estos personajes aparecen asociados a puntos o círculos, ya sea al exterior de ellos o al interior de las vestimentas.

Túnicas trapezoidales pero de base recta se pueden observar en Chusmisa (Figura 6: C7); motivo que presenta un tocado, el cual si bien es plano y con apéndices laterales, tiene también un apéndice superior central. Igualmente en este sitio observamos una interesante variedad de túnicas rectangulares, que van de las simples rellenas, a listadas, con círculos o lunares, signos no identificados y puntos en hilera (Figura 6: C4, C5, C13, C9 y $\mathrm{C} 10$, respectivamente). Los dos últimos motivos son particularmente relevantes ya que presentan varios atributos significativos: flecos en la camisa del primero, que forman un faldellín en el segundo; y el tocado radiado que se repite además en una cabeza sola (Figura 6: $\mathrm{C} 11)^{4}$. Otra especial forma de representar al ser humano es a través de improntas de 

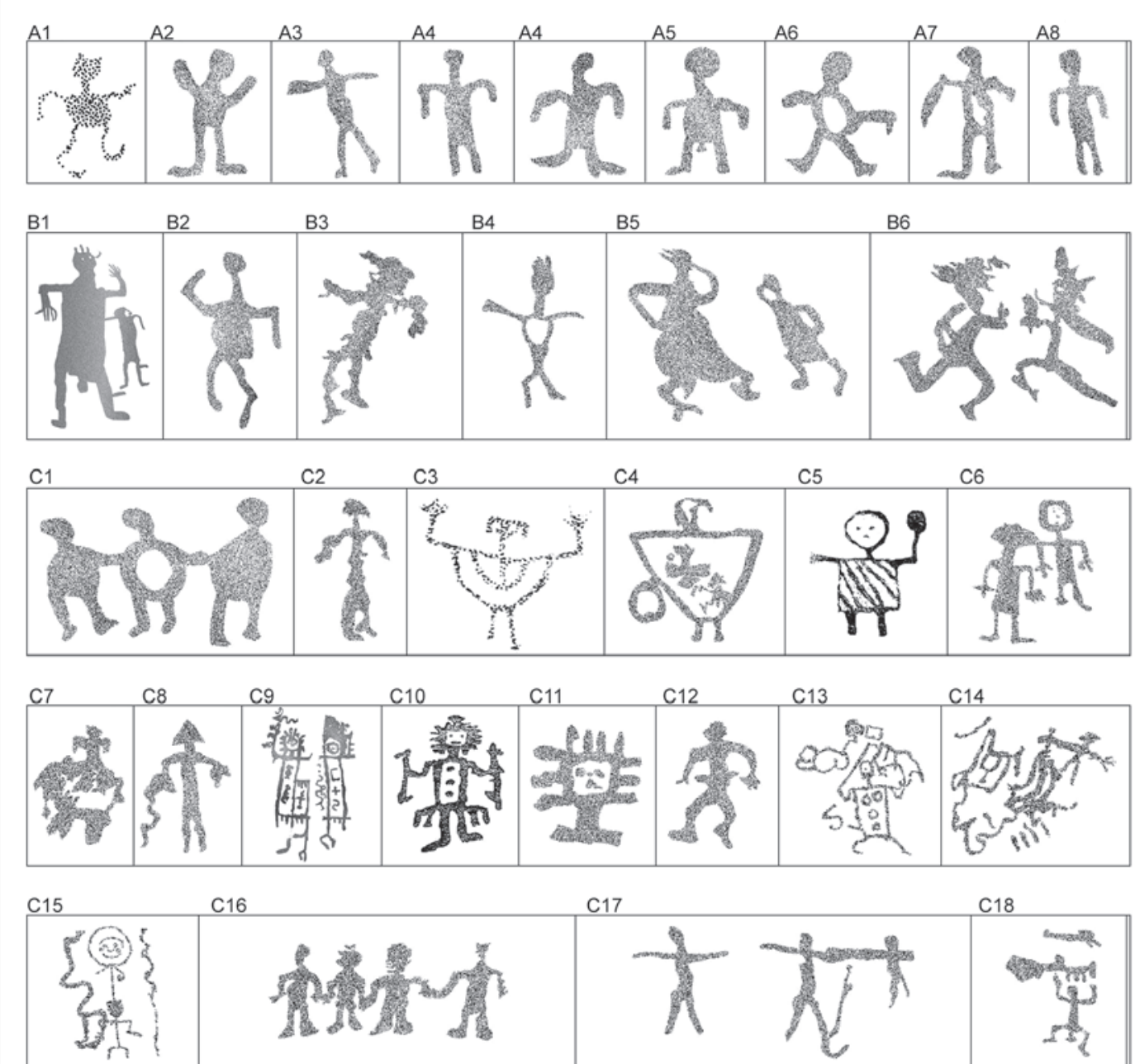

C17
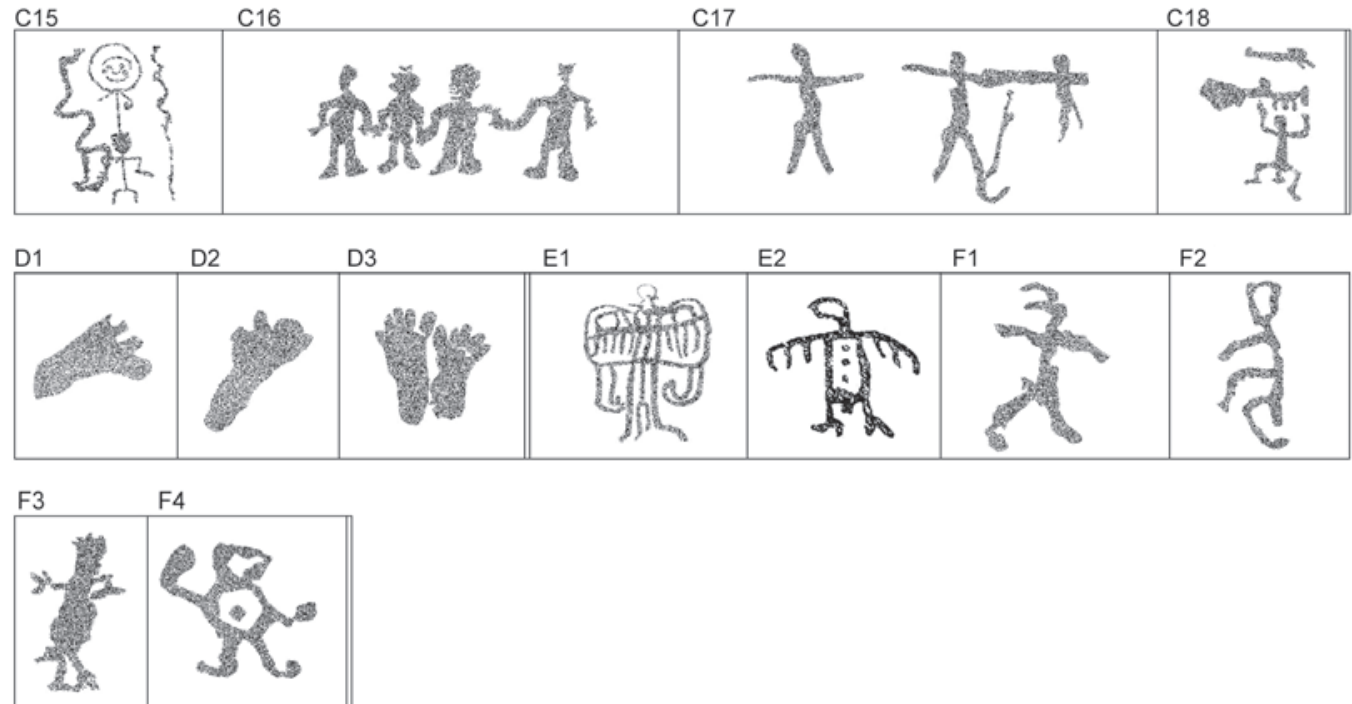

Figura 6. Grupo antropomorfo (Dibujo: Paulina Chávez).

Anthropomorphic group (Drawing: Paulina Chávez). 
pies o huellas en Chusmisa, las cuales se presentan solas o en pares (Figura 6: D1-D3).

Cerrando este grupo están los diseños "antropozoomorfos indeterminados", que como su nombre lo indica mezclan atributos humanos y animales. Excepcionales nos parecen los ejemplares de Camiña (Figura 6: E1 y F2), ambos con características más bien de insecto. El primero, con apéndices paralelos a modo de plumas colgando y un largo pico, podría corresponder a un picaflor, siguiendo los criterios de Chacama (2003). Aves también nos recuerdan otros personajes de Chusmisa que presentan claramente cuerpos humanos y cabeza de falcónida (sensu Chacama 2003; Figura 6: E2-F1); uno de los cuales está vestido con una túnica cuadrangular con puntos en hilera, parecida al antropomorfo antes mencionado (Figura 6: E2 y C10, respectivamente) ${ }^{5}$. Más dudosos son motivos que muestran extremidades, pero que no se pueden clasificar como humanos o animales (Figura 6: F3 y F4).

\section{Variaciones Sobre un Mismo Tema}

Esta revisión de tipos iconográficos ha servido para objetivar la existencia de un repertorio común de imágenes entre los sitios habitacionales con arte rupestre del Complejo Pica-Tarapacá. La máxima expresión de este repertorio la encontramos en Chusmisa, que presenta 29 de las 32 categorías establecidas (Tabla 1). Muchas de ellas alcanzan, además, mayor complejidad de representación que en los otros sitios, particularmente en lo que respecta a las figuras o signos geométricos lineales, fitomorfos, ornitomorfos, camélidos y antropomorfos.

Si Chusmisa es el sitio que expone más variabilidad y complejidad en la representación de las imágenes, Jamajuga representa el polo opuesto. Con 17 de las 32 categorías propuestas, Jamajuga concentra su repertorio en las figuras geométricas más simples (triángulo y cuadrado o rectángulo) y en una forma particular de representar al ser humano. Si bien su variabilidad muestra casi todas las categorías zoomorfas y circulares, estas tampoco desarrollan formas demasiado complejas. Lo consideramos entonces como el sitio más contenido de nuestro universo de estudio, donde el repertorio se muestra acotado: motivos simples y esquemáticos cuya representación pareciera estar más normada.

En posición media, Camiña presenta 21 de las 32 categorías, muchas de las cuales constituyen las expresiones más complejas de todos los sitios.
Particularmente, ciertas variedades del círculo, figuras geométricas simples e indefinidas, sobre todo de líneas onduladas; y también en saurios, batracios e insectos. Son justamente las categorías fuertes de Camiña las que están ausentes en Chusmisa, y que por el contrario, comparte con Jamajuga (triángulo, rectángulo o cuadrado y saurios y batracios), entre otras 10 categorías.

Al establecer este tipo de cruce, observamos que existe una variación entre las categorías que comparten algunos sitios en desmedro de otros. Por ejemplo, Jamajuga-Chusmisa $=14$; CamiñaChusmisa $=18$, siendo sólo 10 categorías las que están presentes en los tres sitios. Constatando una vez más que éstas incluyen las variedades más simples del círculo (simple, con punto central, concéntricos, con apéndice externo y yuxtapuesto), el zigzag y la infaltable figura geométrica indefinida entre los motivos geométricos lineales, camélidos simples y antropomorfos complejos; pero siempre conservando cada una de ellas un modo de representación que es propio casi de cada sitio.

Si bien Tarapacá Viejo y Pukarqollu quedan fuera de esta comparación por la escasa presencia de petroglifos, cualitativamente hemos podido constatar que comparten el repertorio rupestre, ya que presentan elementos idénticos a los otros sitios, fenómeno que como acabamos de observar no ocurre entre los demás asentamientos. Recordemos que estos motivos son los camélidos naturalistas en parejas con orientación oblicua de Tarapacá Viejo, Jamajuga y Camiña (Figura 5: C15, C17 y C19, respectivamente) y el antropomorfo complejo de Pukarqollu y Chusmisa (Figura 6: C2 y C8). Así, Tarapacá Viejo y Pukarqollu participan del circuito de imágenes comunes a un grupo y a una época, pero no las producen en cantidad ni conviven estrechamente con ellas, como ocurre con Jamajuga, Camiña y Chusmisa.

Pese a que hemos podido constatar la existencia de un repertorio común de imágenes y que compartimos la noción de estilo de Davis (1990), entendido como patrón y redundancia de motivos, nos parece prematuro hablar de estilos propiamente tales, puesto que muchas veces supone connotaciones cronológicas y étnicas que aún desconocemos. Sin embargo, hoy contamos con un cuerpo mayor de evidencia comparativa cuya variabilidad nos permite trabajar con el concepto de "replicación" del mismo Davis, en un nivel de resolución intermedio. Recordemos que este autor entiende por 
replicación la "producción secuencial de morfologías materiales similares -formas materiales imaginadas o hechas que son siempre 'artefactos' y frecuentemente imágenes- que son sustituibles por una y otra en contextos sociales de usos específicos" (Davis 1996:1) ${ }^{6}$. En nuestro caso, nos referimos a la replicación de figuras geométricas de forma diferente en cada sitio.

Atribuimos este uso diferencial al modo particular que cada población elige para representar estos motivos, obteniendo una gran variabilidad al interior de las categorías propuestas (p.ej., círculo concéntrico). Esto se explicaría porque, según Davis (1996), no existen sustitutos perfectos (ni artefactos ni sinónimos semánticos), sino que la sustitución es una propiedad emergente de una tradición de producción, pero nunca dada. Ésta debe ser organizada de una manera particular y, por lo tanto, varía según los modos cambiantes de usar artefactos o de las razones para usarlos.

Dicha situación explicaría, por otra parte, que ese uso diferencial también tenga relación con el énfasis que se le da a la representación de ciertas figuras geométricas en cada sitio, es decir, en la elección de las que más se representa. Esto, entonces, estaría aludiendo a un acceso diferencial al significado propio de lo abstracto, que actuaría como código interno entre los grupos locales versus los foráneos. Así, los motivos serían sustituibles según las características particulares (culturales) de cada grupo.

Si pensamos que "la replicación siempre está acompañada por la producción (a veces deliberada) de morfología insustituible" (Davis 1996:2) ${ }^{7}$, podemos entender el uso que hace cada sitio, en particular, de ciertas imágenes más representacionales o figurativas (como insectos y antropomorfos) que acompañan a lo abstracto. Esto se sumaría a la especificidad y particularidad que adquiere la representación visual del conjunto de imágenes representadas en cada sitio. En cierta forma, el concepto de "replicación" antecede el de estilo, toda vez que contribuye a discriminar las diferentes tendencias -o subestilos- al interior de aquello que a futuro podamos denominar estilo de arte rupestre Pica-Tarapacá.

Interpretamos esta situación, la insistencia en la reproducción del motivo más que su forma particular, como un fenómeno que tiene que ver con la representación en cada sitio de elementos identitarios de los diversos grupos que conviven en la región durante el Intermedio Tardío. Identidades que se fundan en ciertos rasgos del Complejo descritos por Uribe (2006), puesto que además de la segmentación de la población con fines productivos, en los sitios se detecta una variabilidad funcional acorde a un sistema económico diversificado. Sistema que denota una intensa producción agrícola, la mantención de prácticas de recolección, el funcionamiento de redes de tráfico, entre otras actividades. En otras palabras, estamos frente a una sociedad compleja, muy diversa, competitiva y en proceso de ampliación.

El énfasis en uno $u$ otro motivo rupestre en cada sitio, entonces, estaría relacionado, al menos en algunos casos, con la mayor o menor presencia concreta de elementos exógenos según lo indican las frecuencias cerámicas. En efecto, en aquellos sitios cuya cerámica superficial y de excavación representa una mayor diversidad de tipos foráneos (p.ej., Altiplano Carangas, Arica y/o Atacama sensu Uribe et al. 2007), es donde justamente aparecen motivos rupestres de raigambre inequívocamente local o tarapaqueña, como la representación de la túnica de urdimbre curva (Vilches y Cabello 2010).

\section{El Arte Rupestre Doméstico en el Contexto Regional}

Un poco más próximos a la comprensión de lo que sucede al interior de los asentamientos habitacionales así como de las variaciones entre los mismos, podemos ampliar nuestra mirada a lo que ocurre con otras expresiones rupestres de la región tarapaqueña, especialmente desde el punto de vista iconográfico. Pese a que la mayoría de las publicaciones con antecedentes rupestres no disponen de un corpus visual amplio debido a su carácter eminentemente descriptivo (Vilches y Cabello 2005), podemos establecer ciertos lineamientos acerca de la selección diferencial de imágenes en sitios de naturaleza diversa-geoglifos, petroglifos sin otra asociación arqueológica más que rutascorrespondientes a un mismo período.

Comparando nuestro inventario de motivos con las referencias visuales publicadas, podemos constatar que si bien se repiten los grandes conjuntos geométricos, antropomorfos y zoomorfos, el repertorio de cada uno difiere en el tipo de motivo así como en la manera en que estos son representados. Por ejemplo, en los geoglifos, antropomorfos y camélidos tienden a representarse en su modo complejo. Vale decir, 
en grupos, muchas veces alineados, con vestimenta para el caso de los antropomorfos y con carga, para el de los camélidos (Briones et al. 2005: Figura 21$)^{8}$. Además, se encuentran bastantes asociaciones entre ambos tipos de motivos (Briones y Chacama 1987: Láms. 3, 7 y 8), formando composiciones que no encontramos en los asentamientos habitacionales. Como lo hemos notado, allí priman los diseños aislados o dispuestos unos junto a otros, pero sin relación evidente ${ }^{9}$. La excepción a esta regla está dada por las representaciones de antropomorfos tipo danzantes (Figura 6: B5 y B6), motivos que también han sido identificados en varios sitios de petroglifos de la zona, como Tarapacá-47 (Núñez y Briones 1967-68) y Suca 7 (Sepúlveda et al. 2005).

Las composiciones de geoglifos y petroglifos aislados recién mencionadas darían cuenta de la actividad caravanera, que estaría corroborada por la presencia de imágenes propias de la zona costera, a la cual se tiene acceso mediante el tránsito por dichas rutas. Así, en los geoglifos se evoca fauna de ambiente marítimo y escenas de actividades como la pesca y caza marinas (Briones et al. 2005: Figuras 10 y 11). Estas imágenes no forman parte del inventario doméstico, pero sí están representadas en petroglifos asociados a rutas (p.ej., Tamentica-1).

Un elemento común a los tres tipos de sitios -doméstico, geoglifos, petroglifos asociados a rutas- es la presencia de motivos zoomorfos tales como cánidos y felinos, aves, saurios y batracios. Para el caso de estos últimos, Briones et al. (2005) mencionan que los lagartos están altamente representados entre el Loa y Camarones, con una amplia variabilidad de diseños. Su presencia diferencial pareciera estar articulando ciertas rutas con otras, como lo harían también el motivo de rombo escalerado (Briones et al. 2005:214) y la figura antropomorfa frontal con báculos y cabeza radiada (Vilches 2006).

El rombo escalerado es clave en el caso de los geoglifos, así como otras figuras geométricas tales como flechas y cruces que están ausentes en los asentamientos domésticos, aunque aparecen documentadas para otros sitios de petroglifos como Tarapacá-47 (Núñez y Briones 1967-68). Por el contrario, triángulos y variantes del círculo están representados tanto en sitios habitacionales como en geoglifos. Un motivo que de igual forma aparece con cierta recurrencia en estos últimos son las figuras, por lo general zoomorfas, encerradas en círculos y que se replica con menor recurrencia en petroglifos.
Tanto en Tamentica- 1 como en Chusmisa se trata de un ave representada al interior de un círculo, en este último caso asociada al único camélido complejo del sitio (Figura 2: E14).

Resulta interesante la representación y distribución del motivo antropomorfo con cabeza radiada portando báculos, podemos encontrarla en Chusmisa, tanto de cuerpo completo como fragmentado (Figura 6: C10 y C11, esta última sólo exhibe su cabeza), en el geoglifo de Cerro Unita y en los petroglifos de Tamentica-1 y Ariquilda 1 (Chacama y Briones 1996: Figura 3). Este modo de representación humana ha sido asociado al personaje que Chacama y Espinosa (1997) relacionan con el mito de Tunupa o Tarapacá, personaje clave en la expansión de Tiwanaku y cuya expresión gráfica sería la "Deidad Central con Báculos" de la Puerta del Sol. La amplia dispersión de esta imagen está bien documentada por los autores, quienes proponen como atributos mínimos su posición (frontal con brazos abiertos en "V"), y atuendo (faldellín y tocado radiado). A ellos nos parece importante agregar la axialidad, observada por Montt $(2002)^{10}$. Este personaje se vincularía con el "hombre-cóndor" (Chacama 2003) que está altamente representado en sitios de petroglifos aislados (p.ej., Suca, Sepúlveda et al. 2005) y que igualmente encontramos en Chusmisa (Figura 6: E2). Relación que Chacama y Briones (1996) establecen a partir de las vestimentas, ya que en ambos casos las figuras visten una túnica cuadrangular decorada con tres elementos en hilera: puntos en Chusmisa y rombos en Ariquilda 1.

Más allá de discutir las posibles vinculaciones mitológicas del personaje con báculos, compartimos la visión de Montt (2002) quien propone que la variabilidad en la representación de esta imagen en distintos contextos debería pensarse en términos de cómo el imaginario local asume y reformula el modelo representativo en desmedro de simples apropiaciones. Así, podríamos visualizar una praxis social activa y en constante transformación, que la autora relaciona con el modelo de "esquema y corrección" de Gombrich donde, "a partir de logros ya establecidos, se realizan combinaciones y reemplazos dando lugar a nuevas obras, en las que es reconocible el esquema primario que les dio forma" (Montt 2002:20). Una visión similar a la de las "replicaciones" de Davis (1996) que discutimos anteriormente.

Si bien el caso de esta imagen es más bien emblemático, es el mejor ejemplo de la existencia de un repertorio común de imágenes, donde sólo 
algunas se potencian y exhiben en todos los tipos de sitios y con una visibilidad importante. La misma situación se repetiría con los motivos de rombo escalerado y lagarto, cuya presencia selectiva podría estar relacionada con el uso diferencial del espacio, sea por razones funcionales (señalética), geográficoecológicas, políticas o incluso étnicas, si pensamos en las distintas vestimentas de los antropomorfos. Aunque este último es un tema que amerita mayor investigación, podemos ya observar que las rutas servirían para el tráfico de bienes tanto materiales como visuales.

Mientras en los sitios de petroglifos asociados a rutas y en los de geoglifos se potencian representaciones de personajes, productos y actividades de diferentes ambientes geográficos a los cuales no todos tienen acceso directo; en los sitios habitacionales aparecen más los camélidos simples y fitomorfos, posiblemente denotando la actividad económica particular que ahí se desarrolla (pastoreo y agricultura). A ellos podemos sumar las figuras geométricas de líneas rectas o "grecas" de Camiña (Figura 3:A4), que han sido identificadas como "chacras" ya que representarían sistemas de regadío (Briones et al. 1999) y que también se encuentran en Suca 13 (Sepúlveda et al. 2005).

Tras este innegable carácter económico del arte rupestre, hoy podemos ofrecer uno más doméstico y cotidiano, ya que en los sitios habitacionales descubrimos una mayor variedad de especies de animales e insectos que no se aprecian en los otros tipos de sitio. Pensamos que esta situación podría responder a una mayor contemplación del entorno, donde las imágenes y sus referentes son más próximos.

Ya no podemos hablar sólo de un grupo especializado que produce y conoce los códigos más bien estandarizados que exhiben los geoglifos (Briones et al. 2005), sino que contamos con una variabilidad enorme que daría cuenta de un acceso masivo a este tipo de representación, tanto en su producción como en su consumo. De todas maneras, pareciera existir también una diferencia entre lo "público" y "lo privado" al interior de los sitios, dada la segregación de espacios simbólicos. Ya hemos mencionado que Chusmisa consagra un sector especial, separado de las actividades cotidianas, para desarrollar las imágenes en su máxima complejidad: el sector del farellón (Vilches 2006). Algo similar es lo que ocurre en otro sitio habitacional con arte rupestre, Suca 7 (Sepúlveda et al. 2005).

En consecuencia, si bien las poblaciones del Complejo Pica-Tarapacá conviven en su cotidianeidad con imágenes, las más complejas y posiblemente foráneas se reservan para sectores especiales, espacialmente segregados, donde se realizarían actividades distintas de las del diario vivir. Existiendo por tanto una segregación al interior de ciertos sitios.

\section{Vicios Privados, Virtudes Públicas}

Si bien a lo largo de estas páginas hemos rehuido establecer un estilo de arte rupestre PicaTarapacá propiamente tal, la evidencia discutida nos enseña que, pese a las variaciones registradas entre contextos privados y públicos en su amplio sentido, todos estos escenarios rupestres se refieren en definitiva a un mismo tema. Dicho tema estaría dado por un registro finito de motivos y por la manera de representarlos. Dimensión iconográfica que presenta diferencias sustanciales, por ejemplo, con los inventarios rupestres conocidos para la región atacameña en el mismo período (p.ej., Núñez et al. 1997; Valenzuela 2004).

En ese sentido, podríamos decir que se establece una suerte de relación de tipo "vicios privadosvirtudes públicas", toda vez que el tema que opera como común denominador es el mensaje inequívoco que estamos frente a una zona cultural particular, a diferencia de lo atacameño, por ejemplo. Esta diferenciación en el hacer se ve refrendada por el comportamiento de los textiles (Agüero 2007), dando cuenta que se trata de una zona de alta movilidad e interacción, que es habitada por diferentes grupos, ya sea locales o provenientes del altiplano. Sin duda, es necesario seguir profundizando esta propuesta tanto a nivel visual como de otras materialidades arqueológicas, y/o cruzarlas, viendo por ejemplo, qué dicen los textiles en relación al arte rupestre. Algo hemos ya esbozado en cuanto a la arquitectura y a la cerámica (Vilches y Cabello 2010), aunque no en términos iconográficos para esta última. Un dato interesante con respecto a la alfarería, sin embargo, es que la cerámica local es monocroma, por lo que cualquier asociación iconográfica tendría que limitarse a tipos foráneos o bien a formas y/o técnicas, tal como ha ocurrido en las comparaciones con textiles.

En síntesis, la variabilidad iconográfica del arte rupestre, sumada a las características de la arquitectura y cerámica de cada sitio donde este se emplaza, nos ha permitido sugerir que los grabados actuaron como catalizadores de las diferencias entre los diversos grupos que dieron cuerpo al Complejo Pica-Tarapacá. Por lo mismo, el arte rupestre habría 
sido clave en la reproducción social de estas poblaciones asegurándoles una impronta común que a la vez opera en estrecha relación con el flujo de los diferentes grupos a lo largo de la región. En ese sentido, visualizamos el rol del arte rupestre no sólo desde un punto de vista ceremonial, sino que también político, donde la impronta en la roca opera como vehículo de diferenciación social y posiblemente étnica. En ese sentido, actuaría como una virtud comunicacional que a su vez permite ciertos "vicios" o interpretaciones más flexibles de los códigos visuales al interior de cada espacio residencial.
Agradecimientos: Proyecto Fondecyt 1030923 a cuyo investigador responsable, Mauricio Uribe, queremos agradecer por invitarnos a trabajar en su estudio. Asimismo, comprometen nuestra gratitud todos los miembros del equipo, en especial aquellos que colaboraron directamente en el registro de arte rupestre en una o más de las diversas campañas de terreno: Claudia del Fierro, Magdalena García, Indira Montt, Gonzalo Pimentel y Simón Urbina. Finalmente, agradecemos a los evaluadores anónimos que contribuyeron a otorgarle mayor claridad a este artículo.

\section{Referencias Citadas}

Adán, L. y S. Urbina

2005 Arquitectura, asentamiento y organización social en las quebradas tarapaqueñas durante los períodos tardíos. Análisis arquitectónico de los sitios Camiña-1, Laymisiña, Carora, Tarapacá Viejo, Caserones-1 y Jamajuga. Informe de avance proyecto Fondecyt 1030923. Manuscrito en posesión de los autores.

Agüero, C.

2007 El Vestuario en la Conformación y Consolidación de la Identidad Cultural de las Poblaciones de Tarapacá durante el Periodo Intermedio Tardío. Tesis para optar al Grado de Magíster en Antropología con mención en Arqueología, Universidad Católica del Norte-Universidad de Tarapacá. Artigas D. y G. Cabello

2004 La otra fauna: Los animales olvidados del arte rupestre del Choapa. Werken 5:121-126. Integrando la Arqueología del Choapa en el Norte Semiárido.

Briones, L.

1985 Definición y comportamiento estilístico de los geoglifos de Cerros Pintados. En Estudios en Arte Rupestre, editado por C. Aldunate, J. Berenguer y V. Castro, pp. 417-418. Museo Chileno de Arte Precolombino, Santiago.

Briones, L. y J. Chacama

1987 Arte rupestre de Ariquilda: Análisis descriptivo de un sitio con geoglifos y su vinculación con la prehistoria regional. Chungara 18:15-66.

Briones, L., P. Clarkson, A. Díaz y C. Mondaca

1999 Huasquiña, las chacras y los geoglifos del desierto: Una aproximación al arte rupestre andino. Diálogo Andino 18:39-61.

Briones, L., L. Núñez y V. Standen

2005 Geoglifos y tráfico prehispánico de caravanas de llamas en el desierto de Atacama (Norte de Chile). Chungara Revista de Antropología Chilena 37:195-223.

Chacama, J.

2003 Hombres, pájaros y hombres-pájaros. Análisis de figuras humanas y aves sobre roca. Quebrada de Aroma, sitio Ariquilda 1, extremos norte de Chile. Ponencia presentada en el 51 Congreso Internacional de Americanistas, Santiago.

Chacama J. y L. Briones

1996 Arte Rupestre en el Desierto Tarapaqueño, Norte de Chile. Boletín SIARB 10:41-51.
Chacama, J. y G. Espinosa

1997 La ruta de Tarapacá: análisis de un mito y una imagen en el norte de Chile. Actas del XIV Congreso Nacional de Arqueología Chilena, Tomo 2, pp. 769-792. Museo Regional de Atacama, Copiapó.

Davis, W.

1990 Style and history in art history. En The Uses of Style in Archaeology, editado por M. Conkey y C. Hastorf, pp. 18-31. Cambridge University Press, Cambridge.

1996 Replications. Archaeology, Art History, Psychoanalysis. The Pennsylvania State University Press, University Park, Pennsylvania.

Espinosa, G.

1998 Lari y Jamp'atu, ritual de lluvia y simbolismo andino en una escena de arte rupestre de Ariquilda 1. Norte de Chile. Chungara 28:133-157.

Gallardo, F.

2009 Sobre la composición y la disposición en el arte rupestre de Chile: consideraciones metodológicas e interpretativas. Magallania 37:85-98.

Llamazares, A.M.

1993 Arte Rupestre de las Quebradas de Guatacondo y Quisma, Norte de Chile. Boletín SIARB 7:38-47.

Montt, I.

2002 Faldellines del Período Formativo en el Norte Grande: un ensayo acerca de la historia de su construcción visual. Estudios Atacameños 23:7-22.

2004 Elementos de atuendo e imagen rupestre en la subregión de río Salado, Norte Grande de Chile. Actas XV Congreso de Arqueología Chilena Chungara Revista de Antropología Chilena Vol. 36 Número Especial, Tomo 2, pp. 651-661.

Moragas, C.

1993 Antecedentes sobre un pukara y estructuras de cumbre asociadas a un campo de geoglifos en la Quebrada de Tarapacá, área de Mocha, I Región. Actas del XII Congreso Nacional de Arqueología Chilena, Temuco, 14 al 19 de octubre. Boletín del Museo Regional de la Araucanía 4, Tomo II, pp. 25-39.

Moreno, P.

1986 Arte Rupestre del Valle de Camiña Sector Compe - 1 Prov. de Tarapacá. Memoria para optar al Grado de Licenciado en Teoría e Historia del Arte. Universidad de Chile, Facultad de Arte, Depto. Teoría de las Artes, Santiago. 
Mostny, G.

1970 La subárea arqueológica de Guatacondo. Boletín del Museo Nacional de Historia Natural XXIX (16):271-287. Santiago.

Núñez, L.

1976 Geoglifos y tráfico de caravanas en el desierto chileno. Homenaje al Dr. Gustavo Le Paige, SJ, editado por H. Niemeyer, pp. 147-201. Universidad del Norte, Antofagasta.

1985 Petroglifos y tráfico en el desierto chileno. En Estudios en Arte Rupestre, editado por C. Aldunate, J. Berenguer y V. Castro, pp. 243-64. Museo Chileno de Arte Precolombino, Santiago.

Núñez, L. y L. Briones

1967-68 Petroglifos del sitio Tarapacá-47 (Provincia de Tarapacá). Estudios Arqueológicos 3-4:43-75.

Núñez, L., I. Cartagena, J.P. Loo, S. Ramos, T. Cruz, T. Cruz y H. Ramírez

1997 Registro e investigación del arte rupestre de la cuenca de Atacama (Informe Preliminar). Estudios Atacameños 14:307-325.

Santoro, C y P. Dauelsberg

1985 Identificación de indicadores tempo-culturales en el arte rupestre del extremo norte de Chile. En Estudios en Arte Rupestre, editado por C. Aldunate, J. Berenguer y V. Castro, pp. 69-86. Museo Chileno de Arte Precolombino, Santiago.

Sepúlveda, M., Romero, A. y L. Briones

2005 Tráfico de caravanas, arte rupestre y ritualidad en la quebrada de Suca (extremo norte de Chile). Chungara Revista de Antropología Chilena 37:225-243.

Tolosa, B.

1967 Descripción de los petroglifos de la zona arqueológica de Tamentica. Revista de la Universidad del Norte 3:79-88, Antofagasta.
Uribe, $\mathrm{M}$.

2006 Arqueología de Pica-Tarapacá (Norte de Chile): Reflexiones acerca de la complejidad y desigualdad social en los Andes Centro Sur (1000-1450 DC). Estudios Atacameños 31:91-114.

Uribe, M., Sanhueza, L. y F. Bahamondes

2007 La cerámica prehispánica tardía de Tarapacá, sus valles interiores y costa desértica, norte de Chile (ca. 900-1.450 d.C.): Una propuesta tipológica y cronológica. Chungara Revista de Antropología Chilena 39:143-170.

Valenzuela, D.

2004 Paisaje, Senderos y Arte Rupestre de Quesala, Puna de Atacama. Chungara Revista de Antropología Chilena Vol. 36 Número Especial, Tomo 2, pp. 673-686.

Vilches, F.

2006 Arte rupestre y vida cotidiana en Chusmiza, Región de Tarapacá. En Arte Americano: Contextos y Formas de Ver. Terceras Jornadas de Historia del Arte, editado por J.M. Martínez, pp. 63-68. RIL Editores, Santiago.

Vilches, F. y G. Cabello

2005 Variaciones sobre un mismo tema: el arte rupestre asociado al Complejo Pica-Tarapacá en los sitios Camiña-1 y Jamajuga, Informe de avance Proyecto Fondecyt 1030923. Manuscrito en posesión de las autoras.

2006 De lo público a lo privado: el arte rupestre asociado al Complejo Pica-Tarapacá. Actas del V Congreso Chileno de Antropología: Antropología en Chile Balance y Perspectivas, Tomo I, pp. 358-369, Colegio de Antropólogos de Chile, Santiago.

2010 Arte rupestre y asentamiento en el Complejo PicaTarapacá: las imágenes como indicadores de identidad y complejidad social. Actas del XVII Congreso de Arqueología Chilena, Tomo 2, pp. 671-680. Universidad Austral, Valdivia.

\section{Notas}

1 Para evitar confusiones, en adelante nombraremos al sitio Camiña-1 sólo como Camiña.

2 Tal vez un análisis métrico de los círculos, tanto del diámetro como del grosor del surco por ejemplo, podría arrojar diferencias importantes.

3 Figuras zoomorfas encerradas en círculos aparecen con mayor recurrencia en los geoglifos, si bien durante recientes estudios en Tamentica-1, pudimos observar un petroglifo también con un ornitomorfo encerrado.

4 Este modo particular de representar al antropomorfo ha sido asociado al personaje "Frontal con Báculos" de la Puerta del Sol Tiwanaku y que sería la expresión grafica del mito de Tunupa o Tarapacá, clave en la expansión de esta cultura, lo cual a su vez explicaría su amplia presencia en la zona (Chacama y Espinosa 1997). Para otras perspectivas, ver Montt (2002).

5 Una asociación similar es justamente la que ha permitido a Chacama (2003) establecer un vínculo entre el "personaje frontal de los báculos" y este "hombre-cóndor", que también está altamente representado en los sitios de petroglifos (p.ej., Suca en Sepúlveda et al. 2005).

6 Traducción de las autoras.

7 Traducción de las autoras.

8 Briones et al. (2005) señalan la recurrencia del tipo de atuendo que denominan "patrón Cerro Pintados". Siguiendo a Briones (1985) y Santoro y Dauelsberg (1985) este diseño tendría un origen alóctono vinculado al noroeste argentino, que estaría también presente en Atacama y Santa Bárbara.

9 Para la diferencia entre composición y disposición ver Gallardo (2009).

10 Esta autora identifica también la vestimenta de este personaje con el "faldellín desdoblado" que dataría del Formativo Tardío en Chorrillos. Además, señala una recurrencia en la asociación de este faldellín y el tocado radial (Montt 2004), y que serían exhibidos por antropomorfos construidos bajo un esquema axial de desdoblamiento especular (Montt 2002:17). 